\title{
FEMINICÍDIO: DA CONIVÊNCIA DO ESTADO À NECESSIDADE DE CAPACITAÇÃO DO SISTEMA DE JUSTIÇA CRIMINAL
}

\author{
Fábia Lopes Gomes da Silva ${ }^{1}$
}

Resumo: Este artigo objetiva revelar que as dificuldades para coibir a violência letal contra as mulheres nas relações domésticas e familiares estão relacionadas, entre outros aspectos, à remota conivência do Estado que ratificou os desmandos da cultura patriarcal no Brasil, por mais de 500 anos. Para tanto, a metodologia aplicada foi a realização de estudos de caso e a análise da produção feminista que contribuiu para a criminalização de condutas machistas e misóginas, bem como da dogmática processual penal para aplicação da qualificadora do Feminicídio pelo Tribunal do Júri. Como resultado, aponta-se a necessidade de capacitação do Sistema de Justiça Criminal.

Palavras chaves: Feminismo; Feminicídio; Misoginia; Sistema de Justiça Criminal; Tribunal do Júri.

\section{FEMINICIDE: FROM THE CONNIVENCE OF THE STATE TO THE NEED FOR TRAINING IN THE CRIMINAL JUSTICE SYSTEM}

Abstract: This article aims to reveal that the difficulties in restraining lethal violence against women in domestic and family relations are related, among other aspects, to the remote connivance of the State that ratified the abuses of patriarchal culture in Brazil, for 500 years. The methodology applied was the carrying out of case studies and the analysis of feminist production that contributed to the criminalization of sexist and misogynist conduct, as well as criminal procedural dogmatics for the application of the Qualifier of Feminicide by the Jury Court. The result points to the need for training in the Criminal Justice System.

Keywords: Feminism; Feminicide; Misogyny; Criminal Justice System; Jury Court.

\section{Introdução}

Apesar de a violência contra as mulheres, letal ou não, estar sendo tratada com maior rigor pelo ordenamento jurídico brasileiro ${ }^{2}$, é possível observar a dificuldade de coibir a sua prática no âmbito das relações domésticas e familiares, e no espaço público de uma forma geral. Isso pode ser comprovado pelos inúmeros casos que são registrados cotidianamente nas

\footnotetext{
${ }^{1}$ Mestranda em Direito pela Universidade Católica de Pernambuco (PPGD/Unicap). Bolsista da CAPES. Feminista, Pesquisadora, Advogada (Unicap), Jornalista (UFPE) e Radialista (UFPE). Diretora do Instituto Diversidade, Gênero e Educação (IDGE). Endereço postal: Rua do Bom Pastor, no 1505, AP. 303E, Edf. Morada Umbuzeiro, Iputinga, Recife/PE, CEP: 50.670-260. E-mail: fabialgomes@ gmail.com.

${ }^{2}$ O STJ não permite o uso da Transação Penal e da Suspensão Condicional do Processo (Súmula 536), a substituição da pena privativa de liberdade por restritivas de direitos (Súmula 588) e o Princípio da Insignificância (Súmula 589) nos crimes e contravenções penais cometidos no âmbito das relações domésticas. Além disso, as leis $\mathrm{n}^{\mathrm{o}}$ 13.641/2018 e $\mathrm{n}^{\circ}$ 13.827/2019 tipificam o crime de descumprimento das medidas protetivas de urgência e a autorizam a sua concessão pela autoridade policial, respectivamente.
} 
delegacias, especializadas ou não; bem como pelo acúmulo de processos que tramitam nas varas de violência doméstica e familiar contra a mulher instaladas em todo o Brasil ${ }^{3}$. Quanto à violência letal, o Instituto Igarapé (2020) indica que cerca de 17 mil brasileiras foram mortas intencionalmente no país entre 2015 e 2018. Em Pernambuco, esse número é de 1.470 vítimas, no período de 01/01/2015 a 31/10/2020 (PERNAMBUCO, 2020).

Diante deste cenário, o presente artigo tem como objetivo demostrar que os números atuais da violência perpetrada pelos homens contra as mulheres são resultado da conivência do Estado brasileiro que, durante séculos, tolerou a sua prática, principalmente no âmbito das relações domésticas e familiares. Em seguida, a proposta é fazer um breve retrospecto da estratégia de positivação das condutas machistas e misóginas no ordenamento jurídico brasileiro - no Código Penal, especialmente - utilizada pelo Movimento Feminista, com vistas a garantir às mulheres o direito de viver e, mais ainda, viver uma vida sem violência.

Conduzindo o debate para o campo do Sistema de Justiça Criminal, serão apresentadas as dificuldades que este encontra para aplicar a recente qualificadora instituída pela Lei $\mathrm{n}^{\text {o }}$ 13.104/2015; além de apresentar o conceito de Feminicídio sob a ótica de pesquisadoras feministas que buscam contribuir com a devida caracterização do fenômeno misógino.

Na sequência, o objetivo é expor as orientações de doutrinadores do Direito quanto ao processamento adequado destes crimes, que são de competência do Tribunal do Júri; bem como as contribuições do Governo Federal para assegurar que as mortes de mulheres no Brasil sejam investigadas, processadas e julgadas sem a interferência de valores patriarcais, conforme previsto na publicação Diretrizes Nacionais para investigar, processar e julgar com perspectiva de gênero as mortes violentas de mulheres ${ }^{4}$.

Por fim, serão analisadas as Sentenças de Pronúncia - "decisão interlocutória de admissibilidade da acusação" (NUCCI, 2014, p. 70) - de dois crimes letais praticados contra duas jovens mulheres em Pernambuco, após a sanção da Lei $\mathrm{n}^{\circ} 13.104 / 2015$, observando a importância do papel do juízo na devida aplicação da qualificadora do Feminicídio.

Do ponto de vista metodológico, a presente pesquisa sociojurídica (OLIVEIRA, 2015, p. 15), possui caráter híbrido, uma vez que a opção para se chegar aos resultados que serão apresentados ao longos dos capítulos foi: I) realizar um estudo bibliográfico tanto da

\footnotetext{
${ }^{3}$ De acordo com o CNJ, em 2018, tramitavam na Justiça do país mais de um milhão de processos referentes à violência doméstica contra a mulher, o que corresponde, em média, a 1 processo para cada 100 brasileiras.

${ }^{4}$ Publicação das secretarias nacionais de Políticas para Mulheres e de Segurança Pública, com apoio da ONU Mulheres e Embaixada da Áustria.
} 
produção feminista sobre o processo de criminalização da violência contra as mulheres no Brasil; quanto da dogmática processual penal para a correta aplicação da qualificadora do Feminicídio no rito do Tribunal do Júri; e, II) promover estudos de casos que tiveram grande repercussão midiática e, de alguma forma, influenciaram o Sistema de Justiça Criminal e a Política de Enfrentamento da Violência contra as Mulheres no Estado de Pernambuco.

\title{
2. Da "licitude" do Feminicídio à inconstitucionalidade da "legítima defesa da honra"
}

Os dados da violência contra as mulheres apresentados na introdução deste estudo remontam à construção histórica do ordenamento jurídico brasileiro no qual, durante cerca de 227 anos, o marido que "achando" a mulher em adultério, ou que apenas suspeitasse da traição, poderia matá-la, "licitamente", conforme Título XXXVIII, do Livro V, das Ordenações Filipinas ${ }^{5}$, in verbis:

\begin{abstract}
Achando o homem casado sua mulher em adulterio, licitamente poderá matar assi a ella, como o adultero, salvo se o marido for peão, e o adultero Fidalgo, ou nosso Dezembargador, ou pessoa de maior qualidade. Porém, quando matasse alguma das sobreditas pessoas achando-a com sua mulher em adulterio, não morrerá por isso mas será degradado para Africa com pregão na audiencia pelo tempo, que aos Julgadores bem parecer, segundo a pessoa, que matar, não passando de trez annos.

E não sómente poderá o marido matar sua mulher e o adultero, que achar com ella em adultério, mas ainda os pôde licitamente matar, sendo certo que lhe cometterão adultério; e entendendo assi provar, e provando depois o adulterio per prova licita e bastante conforme à Direito, será livre sem pena alguma, salvo nos casos sobreditos, onde serão punidos segundo acima dito he (BRASIL, 1603-1830, grifos nossos).
\end{abstract}

É importante observar que a legislação colonial também permitia ao marido matar o amante da esposa, desde que este tivesse uma condição social inferior àquela ocupada pelo agente traído. Nesta mesma época, outras atrocidades eram cometidas contra as populações negras e indígenas, de forma lícita, seja por particulares, seja pelo próprio Estado brasileiro. Isso demonstra que a violência é um fenômeno presente no nosso país, em todas as épocas históricas. Porém, nem todas as suas formas foram consideradas crimes, estando a classificação de um ato como criminoso ou não relacionada a diferentes aspectos sociais. Dentre eles, está o lugar em que o sujeito, contra o qual se perpetra a violência, ocupa na sociedade.

Em outras palavras, no Brasil e em outras partes do mundo, o fator determinante para que uma conduta seja considerada ilícita não é a sua natureza, mas, sim, a condição social de

\footnotetext{
${ }^{5}$ As Ordenações Filipinas foi o diploma penal que vigorou por mais tempo no Brasil, de 1603 a 1830, quando sobreveio o Código Criminal do Império.
} 
“inferioridade humana" da vítima, construída culturalmente, mediante as relações de poder vigentes na sociedade. Assim, matar uma mulher naquela época, em determinados casos, apesar da extrema violência do ato, não era crime ${ }^{6}$.

O Estado brasileiro, omisso durante séculos, só criminalizou, de forma contundente, a violência no âmbito doméstico e familiar em 2006, com a sanção da Lei no 11.340 (Lei Maria da Penha). Em 2015, com a Lei n 13.104, o Brasil qualificou, mesmo que tardiamente, o assassinato de mulheres "por razão da condição de sexo feminino" como Feminicídio, tentando desfazer o dano irreparável de um dia ter autorizado "licitamente" a prática do crime.

Nesse caminhar, a conquista mais recente veio da mais alta corte do Judiciário brasileiro. No início de 2021, o Supremo Tribunal Federal (STF), por unanimidade, firmou entendimento de que a tese da "legítima defesa da honra" é inconstitucional por contrariar os princípios da dignidade da pessoa humana, da proteção à vida e da igualdade de gênero, previstos na Carta Magna. A decisão referendou a medida cautelar concedida pelo ministro Dias Toffoli, relator da Arguição de Descumprimento de Preceito Fundamental (ADPF) $779^{7}$.

A ADPF 779 foi suscitada por ainda perdurar nas sessões do Tribunal do Júri do país veredictos que absolvem réus processados pela prática de Feminicídios com fundamento na nefasta tese da defesa de suas honras. O ministro-relator, contudo, no seu voto, declarou que a tese "corresponde, na realidade, a recurso argumentativo/retórico odioso, desumano e cruel utilizado pelas defesas de acusados de feminicídio ou agressões contra mulher para imputar às vítimas a causa de suas próprias mortes...” (BRASIL, 2021).

Para rechaçar o novo entendimento jurisprudencial, alguns operadores do direito, sobretudo advogados e defensores que atuam no âmbito do rito especial, têm afirmado que a restrição ao uso da tese perante o Conselho de Sentença limita a plenitude de defesa, característica intrínseca ao Tribunal do Júri prevista no Art. 5, XXXVIII, alínea "a", da Constituição Federal. Em outras palavras, esses operadores do Direito, por meio de mera tecnicidade, desejam manter ad eaternum um fundamento que, inclusive, não consta no atual ordenamento jurídico penal brasileiro. Como disse TOFFLI, “foi imbuído desse espírito e para evitar que a autoridade judiciária absolvesse o agente que agiu movido por ciúme ou

\footnotetext{
${ }^{6}$ O Direito Civil brasileiro, por sua vez, ratificou a condição de subalternidade das mulheres em relação aos homens durante quase 500 anos, especialmente quando da celebração do casamento, o que as tornava relativamente incapazes. A mulher casada só veio a adquirir capacidade civil em 1962, com a sanção da Lei ${ }^{\circ}$ 4.121 (Estatuto da Mulher Casada). No seio da família, portanto, as mulheres estavam à mercê dos desmandos do marido, inclusive sujeitas à violência por ele perpetrada.

${ }^{7}$ Ajuizada pelo Partido Democrático Trabalhista (PDT), a ADPF teve o objetivo de suscitar interpretação, conforme à CF, dos arts. 23, inciso II, e 25, caput e parágrafo único, do CP; ao art. 65 do CPP; e também ao art. 483, III, § $2^{\circ}$, do CPP.
} 
outras paixões e emoções que o legislador ordinário inseriu no atual Código Penal a regra do art. $28^{8 \%}$ (BRASIL, 2021).

Dessa forma, as atuais normativas, acompanhadas de novos entendimentos jurisprudenciais e doutrinários, ofertam aos operadores do Sistema de Justiça Criminal delegados(as), promotores(as) e juízes(as) - uma série de instrumentos de proteção às mulheres em situação de violência e de punição dos agressores. Isto porque, a Lei Maria da Penha, ao criminalizar o Machismo nas relações domésticas e familiares, permite que o Estado intervenha no cotidiano da vida privada dos envolvidos no conflito, por meio da aplicação das medidas protetivas de urgência, com a proposta de assegurar a integridade física, psicológica, patrimonial, sexual e moral da vítima. A Lei do Feminicídio, entretanto, ao criminalizar a Misoginia - "ódio, desagrado, desconfiança pelas mulheres” (TARSO, 150 a.C., apud LOPES, 2012, p. 490) -, mais do que aumentar a pena dos condenados, tem como objetivo precípuo registrar a real ocorrência do fenômeno na sociedade.

\section{O Feminismo como propulsor da atual estratégia de enfrentamento da violência contra as mulheres no Brasil}

Como mencionado, as mulheres brasileiras estiveram sujeitas à violência letal dos homens, permitida pelo Estado, durante mais de dois séculos. Isto porque, no mundo ocidental, do qual o Brasil faz parte, o Patriarcado, que é um dos seus elementos constitutivos, impõe às mulheres a condição de seres inferiores e, por isso, elas estariam naturalmente sujeitas ao controle masculino. O Patriarcado é, portanto, um sistema de dominação em que as relações sociais são determinadas pela opressão das mulheres, através do controle dos homens, seja de seus corpos - aptidão reprodutiva e sexualidade -, seja de sua capacidade de participação na esfera pública - trabalho remunerado e espaços de poder (BUARQUE, 2013, p. 09).

Por esta razão, os sistemas patriarcais decorrem da ideologia machista que consiste na falsa ideia da supremacia masculina em relação às mulheres e que, portanto, autoriza a prática de atos ofensivos contra elas (SAFFIOTI, 2015, p. 47). Essas condutas podem se manifestar de forma branda ou carregadas de brutalidade, sendo principalmente estas últimas conhecidas como misóginas (LOPES, 2012, p. 495). Assim, nada poderia ser mais misógino

\footnotetext{
8 "Não excluem a imputabilidade penal: I - a emoção ou a paixão".
} 
do que o ato de ceifar a vida de uma mulher, já que a conduta visa exterminar a sua existência, negando-lhe o direito de ocupar não só um lugar na sociedade, mas no próprio mundo.

Opondo-se às atrocidades do sistema patriarcal, machista e misógino, o Feminismo, por sua vez, vem promovendo mudanças radicais nas sociedades modernas há cerca de duzentos anos, com o objetivo de extirpar a subalternidade das mulheres das relações sociais e familiares, e, consequentemente, garantir-lhes o direito de existir e de serem cidadãs em toda a sua plenitude. O Feminismo é, portanto,

a ação política das mulheres em favor da transformação das relações de poder entre homens e mulheres, que incide na transformação da sociedade, através do combate às desigualdades, discriminações, opressões e explorações de sexo, com contribuições, teóricas e práticas, nos campos da organização política, das leis, dos hábitos e costumes, dos saberes e dos governos (BUARQUE, 2013, p. 11).

Com esse viés, o Feminismo, que já havia promovido mudanças no arcabouço legislativo brasileiro na década de $1930^{9}$, encontrou um terreno ainda mais fértil no país durante o período da redemocratização, após o fim do regime militar, especialmente quando da formulação da Carta Magna. Naquele momento, vários sujeitos sociais emergiriam e, entre eles, o Movimento Feminista. A feminista Jacqueline Pitanguy, então presidenta do Conselho Nacional dos Direitos da Mulheres (CNDM), ajudou a Bancada Feminina da Constituinte de 1987 - eram 26 deputadas federais entre os 559 membros da Câmara Federal - a criar o "Lobby do Batom" que, entre outras conquistas, garantiu a inclusão o inciso I, no Art. $5^{\circ}$, da $\mathrm{CF}^{10}$.

Esse movimento, então, teve como resultado principal a entrega da "Carta das Mulheres Brasileiras", em março de 1987, ao presidente da Assembleia Nacional Constituinte, o deputado Ulisses Guimarães (PITANGUY, 2018, p. 47). "Era um manifesto na qual exprimiam sua preocupação com o futuro do País e apresentavam suas propostas para a nova Constituição" (SILVA; GOMIDE, 2020, p. 27).

Dentre as propostas, estava a reivindicação de que o Estado deveria intervir na vida privada, a fim de erradicar a violência praticada contra as mulheres no ambiente doméstico e familiar. Foi com esse objetivo que se inseriu o $\S 8^{\circ}$, no artigo 226, da Carta Magna: "O Estado assegurará a assistência à família na pessoa de cada um dos que a integram, criando mecanismos para coibir a violência no âmbito de suas relações” (BRASIL, 1988).

\footnotetext{
${ }^{9}$ Após uma grande luta das sufragistas, o Código Eleitoral de 1932 instituiu o voto feminino no Brasil.

10 "Homens e mulheres são iguais em direitos e obrigações, nos termos desta Constituição".
} 
Em atendimento a esse preceito constitucional, o Estado brasileiro, pressionado pelo Movimento Feminista, formulou e sancionou a Lei $n^{\circ}$ 11.340/2006 (Lei Maria da Penha). Ou seja, a normativa foi instituída a partir do "projeto jurídico feminista" (SEVERI, 2018, p. 08), indo muito além da saga da Sra. Maria da Penha para criminalizar o seu agressor e denunciar a omissão do Poder Judiciário frente às atrocidades das quais foi vítima. A aprovação da Lei Maria da Penha, em verdade, foi "resultado de uma litigância estratégia feminista, ou de advocacy de movimentos de mulheres brasileiros e latino-americanos, voltada para a institucionalização do papel do Estado brasileiro no enfrentamento da violência contra a mulher" (SEVERI, 2018, p. 86).

Ampliando o entendimento para a Lei $\mathrm{n}^{\mathrm{o}} 13.104 / 2015$, é possível inferir que a instituição do Feminicídio no ordenamento jurídico do país foi, também, uma resposta ao pleito do Movimento Feminista pelo reconhecimento de que uma das motivações pelas quais as mulheres são assassinadas está diretamente ligada à sua condição de sexo em situação de vulnerabilidade, o que jamais pode ser confundido com a antiga ideia de sexo frágil (MARTINS, 2021, p. 283).

Contudo, a estratégia do Feminismo em criminalizar o Machismo e a Misoginia tem sido criticada pela academia sob o argumento de que se trata de mero uso simbólico do poder punitivo, cujo mecanismo tem se mostrado ineficaz para coibir a ocorrência dos crimes contra as mulheres na sociedade. Nesse sentido, Marília Montenegro (2015, p. 112) afirma que "o Direito Penal não constitui meio idôneo para fazer política social, e as mulheres não podem buscar a sua emancipação através do poder punitivo e sua carga simbólica".

Mesmo assim, apesar de compreenderem que o Direito Penal é falho quanto à ressocialização de pessoas que cometeram atos ilícitos, antijurídicos e culpáveis, bem como não oferece nenhuma garantia para a paz social, há feministas que ainda defendem a necessidade de se continuar apostando "no reconhecimento pelo Estado da violência doméstica como um problema social e de ordem pública, investindo-se em desvelar certo problema estrutural de uma sociedade patriarcal através da denúncia das violências ocorridas no âmbito familiar” (MARTINS; GAUER, 2019, p. 151).

Nessa perspectiva, Danielle Souza (2019, p. 33) entende que "trazer à luz o feminicídio - além do valor simbólico ou de sua função promocional - é importante para poder conhecer a real magnitude desta conduta ilícita, contribuindo para a visibilização perante à sociedade dos homicídios de mulheres". 
É também com essa compreensão que Marcela Lagarde afirma que o Feminicídio, se acompanhado da omissão das autoridades públicas, torna-se um "crime de Estado" (2004, p. 05, apud PASINATO, 2011, p. 232). Nessa perspectiva, além de elaborar as leis que criminalizam as práticas machistas e misóginas, o Estado brasileiro também é responsável por criar os mecanismos necessários à sua devida implementação, sob pena de serem cúmplices dos atos criminosos.

Foi com esse entendimento que o Governo de Pernambuco criou, em 2007, a Secretaria da Mulher (SecMulher/PE), que formulou a Política Estadual de Enfrentamento da Violência de Gênero contra as Mulheres, e instituiu espaços de discussão temática: I) a Câmara Técnica para o Enfrentamento da Violência de Gênero contra as Mulheres ${ }^{11}$ do Pacto pela Vida ${ }^{12}$; e, II) o Grupo de Trabalho Interinstitucional sobre Feminicídio (GTIF) ${ }^{13}$.

Este trabalho de articulação e de gestão de serviços especializados realizado pelo Poder Executivo, em paralelo àquele implementado pelo Sistema de Justiça Criminal, está em consonância com as Diretrizes Nacionais para investigar, processar e julgar com perspectiva de gênero as mortes violentas de mulheres. Segundo o documento, a integração entre órgãos dos poderes Executivo e Judiciário contribui para prevenir e reduzir os impactos da violência na vida cotidiana das mulheres (BRASIL, 2016, p. 108).

Além disso, as Diretrizes Nacionais também indicam a necessidade de se promover a capacitação permanente dos operadores do Sistema de Justiça Criminal, especialmente do Poder Judiciário, com vistas a garantir a aplicação adequada da qualificadora do Feminicídio. É o que será abordado nos capítulos a seguir.

\section{4. $O$ conceito de Feminicídio e as dificuldades de aplicação da qualificadora no Brasil}

As normativas (leis Maria da Penha e do Feminicídio), mesmo que tenham usado simbolicamente o Direito Penal, revelaram a existência de condutas machistas e misóginas

\footnotetext{
${ }^{11}$ Criado por meio do Decreto estadual $\mathrm{n}^{\circ}$ 38.576, de 27 de agosto de 2012, o espaço é competente para coordenar a implementação e a execução das ações estratégicas para o enfrentamento da violência contra a mulher no Estado.

${ }^{12}$ O Pacto pela Vida é uma política pública de segurança, criada em 2007, para coibir, de forma específica, os Crimes Violentos Letais Intencionais (CVLI's) no território estadual. A política envolve, além da sociedade civil organizada, o Poder Judiciário, o Ministério Público, a Assembleia Legislativa, os municípios e a União.

${ }^{13} \mathrm{O}$ espaço de articulação, criado pelo Decreto estadual no 44.951, de 04 de setembro de 2017, é formado por membros das secretarias da Mulher, de Defesa Social, de Justiça e Direitos Humanos e de Saúde do Governo do Estado, além do Tribunal de Justiça, do Ministério Público e da Defensoria Pública de Pernambuco.
} 
que, além de ofender a integridade física de milhares de brasileiras, tem ceifado as suas vidas por "razões da condição de sexo feminino".

Assim, adentrando especificamente no Feminicídio e sua caracterização como um crime de ódio contra as mulheres, é importante compreender a diferença entre os termos Feminicídio e Femicídio. Wânia Pasinato (2011, p. 221) identificou que a segunda expressão foi pronunciada pela primeira vez em 1976, por Diana Russell, durante o I Tribunal Internacional de Crimes contra Mulheres, realizado em Bruxelas, na Bélgica. Na ocasião, a palavra Femicídio foi utilizada para designar os assassinatos de mulheres que teriam sido provocados pelo fato de serem mulheres (RUSSELL; RADFORD, 2007, apud PASINATO, 2011, p. 221). Nessa direção, PASINATO (2011, p. 236) encontrou uma classificação do crime elaborada por Ana Carcedo (2000), indicando três grupos distintos:

Femicídio íntimo: aqueles crimes cometidos por homens com os quais a vítima tem ou teve uma relação íntima, familiar, de convivência ou afins (...)

Femicídio não íntimo: são aqueles cometidos por homens com os quais a vítima não tinha relações íntimas, familiares ou de convivência, mas com os quais havia uma relação de confiança, hierarquia ou amizade, tais como amigos ou colegas de trabalho, trabalhadores da saúde, empregadores (...)

Femicídios por conexão: são aqueles em que as mulheres foram assassinadas porque se encontravam na "linha de fogo" de um homem que tentava matar outra mulher, ou seja, são casos em que as mulheres adultas ou meninas tentam intervir para impedir a prática de um crime contra outra mulher e acabam morrendo. (grifos nossos).

Carmen Hein de Campos (2015, p. 105) apresenta um aprimoramento da definição de Femicídio formulada por RUSSELL, como sendo

o fim extremo de um continuum de terror contra as mulheres que inclui uma variedade de abusos físicos e psicológicos, tais como o estupro, a tortura, a escravidão sexual (particularmente a prostituição), o incesto, o abuso sexual contra crianças, agressão física e sexual (...). Qualquer dessas formas de terrorismo que resultem em morte será femicídio.

Nas palavras de CAMPOS (2015, p. 105), o Femicídio “é a forma mais extrema da violência baseada na inequidade de gênero, esta entendida como a violência exercida pelos homens contra as mulheres em seu desejo de obter poder, dominação ou controle”. Marcela Lagarde, por sua vez, afirma que o Feminicídio representa o conjunto de assassinatos de mulheres, acompanhado do silêncio, da omissão, da negligência e da conveniência de autoridades encarregadas de prevenir e erradicar essas atrocidades (2004, p. 05, apud PASINATO, 2011, p. 232). 
No Brasil, o legislador optou por adotar o termo Feminicídio para qualificar os homicídios de mulheres, incluindo o inciso VI, no artigo 121, do Código Penal. Mas, no afã de proteger as mulheres da violência letal, ampliou, em demasia, as possibilidades de subsumir as condutas cometidas durante o ato executório do crime na qualificadora do tipo penal, in verbis.

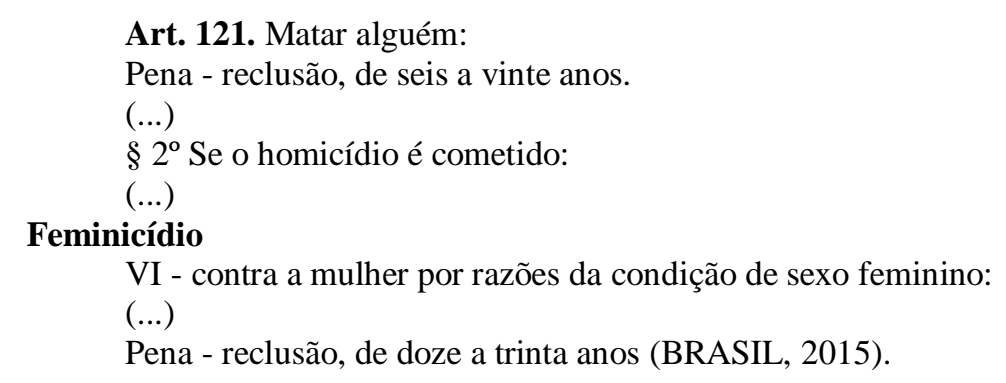

Ou seja, matar uma "mulher por razões da condição de sexo feminino" é uma expressão de grande subjetividade e que provoca questionamentos em relação a quais circunstâncias conduzem à concretização da qualificadora ${ }^{14}$. Ao tentar explicar quais são essas "razões", o legislador acrescentou o $\S 2^{\circ}$-A que, no inciso I, não deixa dúvidas de que os assassinatos de mulheres no seio familiar - praticados por irmãos, pais, tios, sobrinhos, filhos, padrastos, cunhados e outros entes familiares - ou no âmbito das relações domésticas e de afeto - por (ex) maridos, (ex) namorados ou (ex) companheiros - são Feminicídios.

$\S 2^{\circ}$-A Considera-se que há razões de condição de sexo feminino quando o crime envolve:

I - violência doméstica e familiar;

II - menosprezo ou discriminação à condição de mulher (BRASIL, 2015).

Ocorre que, o inciso II, do mesmo $\S 2^{\circ}-\mathrm{A}$, traz a expressão "menosprezo ou discriminação à condição de mulher", o que, mais uma vez, favorece a subjetividade do julgador. Dessa forma, é possível apontar dois cenários prováveis após a sanção de Lei no 13.104/2015 no Sistema de Justiça Criminal: I) todo e qualquer homicídio doloso contra mulher está sendo qualificado como Feminicídio; ou, com maior gravidade: II) Feminicídios estão deixando de ser registrados, invisibilizando a dimensão da ocorrência do crime na sociedade.

${ }^{14}$ O CNJ identificou que o Tribunal de Justiça do Rio Grande do Norte (TJRN), após revisar 1.380 processos que tramitavam como Feminicídio em 2017, observou que apenas 25 deveriam ter a qualificadora (BRASIL, 2018). 
Tentando objetivar o registro do fenômeno misógino em Pernambuco, o Governo do Estado, a partir do Decreto $\mathrm{n}^{\mathrm{o}} 44.950 / 2017^{15}$, indica os elementos que devem ser considerados pela polícia para que o fato seja notificado no Sistema de Mortalidade de Interesse Policial (SIMIP) da Secretaria de Defesa Social (SDS/PE) como Feminicídio, in verbis:

Art. $2^{\circ}$ Considera-se que há razões da condição de sexo feminino, para efeito do registro previsto no art. $1^{\mathrm{o}}$, quando o crime envolve violência doméstica e familiar e/ou menosprezo ou discriminação à condição de mulher. considerados:

Parágrafo único. Para caracterizar as situações referidas no caput, devem ser

I - a existência atual ou anterior de relacionamento íntimo ou afetivo entre o(a) agressor(a) e a vítima;

II - a presença de laços de parentesco, por consanguinidade ou afinidade, entre o(a) agressor(a) e a vítima; ou

III - o menosprezo ou discriminação do(a) agressor(a) com relação à vítima e ao seu corpo, expresso, dentre outras formas, através da prática de violência sexual antes ou após a morte da vítima, ou ainda da mutilação ou desfiguração de seu corpo (PERNAMBUCO, 2017).

Contudo, como será apresentado no capítulo a seguir, o Poder Judiciário é o principal agente do Sistema de Justiça Criminal responsável pela garantia da caracterização adequada do Feminicídio.

\section{O juízo como garantidor da aplicação da qualificadora na Sentença de Pronúncia}

Do ponto de vista processual, o procedimento do Tribunal do Júri é complexo, formado por três fases distintas: i) Da Denúncia à Pronúncia; ii) Preparação em Plenário; e, iii) Julgamento e Proclamação da Sentença (NUCCI, 2014, p. 70). Em razão dessa complexidade, só serão aqui descritos os momentos do rito especial de maior relevância para a caracterização do Feminicídio. Nesse caminho, as Diretrizes Nacionais para investigar, processar e julgar com perspectiva de gênero as mortes violentas de mulheres afirmam que a primeira fase processual (Da Denúncia à Pronúncia) é muito importante, pois é nesse momento onde serão produzidas as provas que irão fundamentar a aplicação da qualificadora na Pronúncia.

É importante que sejam asseguradas condições de participação e proteção para que as vítimas sobreviventes e indiretas, assim como outras testemunhas presenciais ou não presenciais, tragam aos autos informações sobre o local do crime, os meios e instrumentos utilizados na prática do crime, dinâmica dos fatos, atitudes do(a)(s)acusado(a)(s) e da vítima, seu estado emocional em períodos anteriores ao crime, a existência de violência anterior e demais informações que permitam

\footnotetext{
${ }^{15}$ O Decreto, de 04 de setembro de 2017, “dispõe sobre o registro de ocorrência do crime de Feminicídio".
} 
fundamentar a motivação do ato criminoso a fim de que o(a) juiz(a) possa proceder com o correto enquadramento penal na decisão de pronúncia que levará o(a) acusado(a) ao julgamento pelo Conselho de Sentença (BRASIL, 2016, p. 105-106).

Assim, ao final da primeira fase do Tribunal, o juízo poderá: I) pronunciar o acusado, levando o processo para a segunda fase; II) impronunciar do réu, extinguindo-se o processo sem julgamento de mérito; III) desclassificar o crime, remetendo-se o processo ao juízo competente; ou, IV) absolver sumariamente o acusado, quando o processo é encerrado com julgamento de mérito (LIMA, 2020, p. 1438).

Neste ponto, é de suma relevância lembrar que, sendo o caso de pronúncia do acusado, o texto da decisão interlocutória deverá fazer referência à qualificadora do Feminicídio, se assim restar provado na instrução, sob pena de preclusão, como prevê os Arts. $413, \S 1^{\mathrm{o}^{16}}$, e $483, \mathrm{~V}^{17}$, ambos do CPP. Nesse aspecto, apesar do juiz ficar impedido de analisar de forma mais aprofundada a existência das qualificadoras contidas na Denúncia "nada impede que o juiz mencione, por exemplo, que a prova dos autos indica que o réu praticou, em tese, um crime de feminicídio" (BRASIL, 2016, p. 106).

É também nessa fase final da instrução que o juízo poderá fazer uso de dois institutos processuais penais de grande relevância para a garantia da aplicação da qualificadora do Feminicídio, quais sejam: Emendatio Libelli e Mutatio Libelli. No rito especial, o primeiro procedimento está previsto no Art. $418^{18}$ do CPP e deve ser utilizado quando o(a) magistrado(a) identificar que, apesar das condutas que caracterizam o Feminicídio terem sido praticadas durante $\mathrm{o}$ ato executório do crime, a peça acusatória não fez menção à qualificadora. Ou seja, a Emendatio Libelli é o poder-dever do(a) magistrado(a) de modificar a descrição do fato contida na Denúncia, atribuindo-lhe uma definição jurídica diversa, mesmo que isso signifique sujeitar o acusado a pena mais grave (LOPES JR., 2020, p. 1.262).

O segundo instituto em debate (Mutatio Libelli) está previsto no Art. 411, $\S 3^{\text {o19 }}$, do CPP. O dispositivo indica que o(a) juiz(a) deverá fazer uso do Art. $384^{20}$ do diploma

\footnotetext{
16 "A fundamentação da pronúncia limitar-se-á à indicação da materialidade do fato e da existência de indícios suficientes de autoria ou de participação, devendo o juiz declarar o dispositivo legal em que julgar incurso o acusado e especificar as circunstâncias qualificadoras e as causas de aumento de pena".

17 "Se existe circunstância qualificadora ou causa de aumento de pena reconhecidas na pronúncia ou em decisões posteriores que julgaram admissível a acusação".

18 “O juiz poderá dar ao fato definição jurídica diversa da constante da acusação, embora o acusado fique sujeito a pena mais grave".

19 "Encerrada a instrução probatória, observar-se-á, se for o caso, o disposto no art. 384 deste Código".

20 "Encerrada a instrução probatória, se entender cabível nova definição jurídica do fato, em consequência de prova existente nos autos de elemento ou circunstância da infração penal não contida na acusação, o Ministério Público deverá aditar a denúncia ou queixa, no prazo de 5 (cinco) dias, se em virtude desta houver sido instaurado o processo em crime de ação pública, reduzindo-se a termo o aditamento, quando feito oralmente".
} 
processual, antes da formulação da Sentença de Pronúncia, ao identificar que, após a instrução probatória, há nos autos alguma prova de elemento ou de circunstância do crime que não estava descrita na peça acusatória. Ou seja, quando o fato narrado na inicial não corresponder aos fatos provados na instrução processual, cabendo ao Ministério Público aditar a Denúncia.

No caso do Parquet se negar a fazer a adição, o(a) magistrado(a) poderá, por analogia, fazer uso do Art. $28, \S 1^{021}$, do CPP, enviando o processo ao procurador-geral para que este faça o devido aditamento ou designe outro membro do MP para que o faça. No caso de o procurador-geral entender que não há necessidade de aditar a exordial, o(a) juiz(a) deverá acatar a decisão.

A Mutatio Libelli, enfim, deve ser utilizada pelo(a) magistrado(a) quando este(a) perceber, após a instrução criminal, que há uma alguma prova nos autos que caracteriza o Feminicídio, mas a qualificadora não foi reconhecida na Denúncia. Nas palavras de Nucci (2014, p. 109), “as qualificadoras, que possuírem o mínimo necessário esteio na prova produzida, devem ser mantidas para a apreciação do juiz natural da causa, o Tribunal do Júri”.

Diante do exposto, é possível afirmar que, entre os órgãos que compõem o Sistema de Justiça Criminal - Polícia Civil, Ministério Público e Poder Judiciário -, vem deste último, especificamente na figura do juízo, a responsabilidade por garantir que a qualificadora do crime de Feminicídio seja devidamente caracterizada na Sentença de Pronúncia.

A segunda fase do rito do Júri é intermediária (Preparação em Plenário), posicionando-se entre a formação da culpa e o juízo de mérito, iniciada após o trânsito em julgado da decisão de pronúncia. No caso dos Feminicídios, as Diretrizes Nacionais orientam que, nesta fase, o juízo deve estar atento quanto às teses de defesa que podem ofender à memória das vítimas, a exemplo da inconstitucional "legítima defesa da honra" (BRASIL, 2021).

Por fim, o juízo de apreciação do mérito da causa ocorre na terceira fase do rito especial (Julgamento e Proclamação da Sentença). É nesse momento que os juízes(as) leigos(as) - jurados(as) - darão o veredicto, resultando na procedência (condenação do acusado) ou improcedência (absolvição do réu) da ação penal, e no reconhecimento ou afastamento das qualificações do crime (LOPES JR., 2020, p. 1.326). Essa terceira fase apresenta também grande complexidade, optando-se, mais uma vez, por descrever apenas

\footnotetext{
21 “Se a vítima, ou seu representante legal, não concordar com o arquivamento do inquérito policial, poderá, no prazo de 30 (trinta) dias do recebimento da comunicação, submeter a matéria à revisão da instância competente do órgão ministerial, conforme dispuser a respectiva lei orgânica".
} 
aqueles momentos específicos que são de fundamentais para a caracterização do Feminicídio, quais sejam: i) Formulação do questionário; ii) Votação; e, iii) Proclamação da Sentença.

O questionário é o conjunto dos quesitos elaborados pelo(a) juiz(a) presidente, que serão submetidos à votação pelo Conselho de Sentença, para veredicto final: I) Procedência, II) Improcedência, ou III) Procedência parcial à imputação. Para cumprir esta tarefa, o(a) magistrado(a) deve levar em consideração o teor dos interrogatórios, das alegações das partes e da Sentença de Pronúncia, sendo inviável elaborar um quesito relativo a uma qualificadora que não foi citada na peça interlocutória. Por esta razão, o reconhecimento da qualificadora do crime de Feminicídio na Sentença de Pronúncia é de fundamental importância.

Quanto à formulação dos quesitos relacionados às qualificadoras, estes deverão ser apresentados separadamente, havendo um quesito para cada qualificadora que, por ventura, tenha sido mencionada na Pronúncia (NUCCI, 2014, p. 273). Isso significa que, nos crimes de Feminicídio, um dos quesitos deve ser formulado especificamente para o reconhecimento da qualificadora pelo Conselho de Sentença. Caso isso não aconteça, o Ministério Público pode impugnar o procedimento, solicitando a formulação da questão específica.

$\mathrm{O}(\mathrm{A})$ juiz(a) irá esclarecer cada quesito aos(às) jurados(as) e, não havendo dúvidas, todos os envolvidos irão se dirigir à sala especial de votação (Art. $485^{22}$ do CPP). Dados os votos, será registrada pelo escrivão a votação de cada quesito, bem como o resultado do julgamento. Encerrando o rito do Júri, o(a) presidente lerá a Sentença final em plenário.

Neste último momento, como indicam as Diretrizes Nacionais, é importante que o(a) magistrado(a) transmita ao réu e à toda a sociedade que o Feminicídio é um crime baseado nas relações de poder entre os sexos, podendo ser evitado a partir da transformação dos valores culturais que alimentam a violência contra as mulheres (BRASIL, 2016, p. 108).

Observa-se, portanto, que a responsabilidade do(a) juiz(a) não se resume à correta qualificação do Feminicídio na Sentença de Pronúncia. Também é obrigação do(a) magistrado(a) discursar em plenário, demonstrando que o Estado brasileiro repudia veementemente a prática do crime misógino.

\section{Estudos de caso: dois Feminicídios, duas Sentenças de Pronúncia}

\footnotetext{
22 "Não havendo dúvida a ser esclarecida, o juiz presidente, os jurados, o Ministério Público, o assistente, o querelante, o defensor do acusado, o escrivão e o oficial de justiça dirigir-se-ão à sala especial a fim de ser procedida a votação".
} 
Os crimes que constituem o objeto de análise deste artigo foram cometidos contra duas mulheres moradoras do Recife. A primeira vítima é M.A.A.S., de 19 anos, morta pelo padrasto, no dia 19/06/2015. A segunda é T.M.S.A., de 28 anos, vitimada fatalmente pelo vizinho, no dia 05/04/2017. Os dois crimes foram cometidos após a vigência da Lei $n^{\circ}$ 13.104/2015. Contudo, apenas um deles foi qualificado como Feminicídio, demostrando a fragilidade do Sistema de Justiça Criminal na devida aplicação da qualificadora.

\subsection{M.A.A.S. (Processo $n^{\circ}$ 0000686-77.2015.8.17.0790): o espetáculo da mídia e a omissão do juiz}

A jovem foi criada pelo padrasto, em virtude do abandono afetivo-financeiro-paterno. A sua mãe, que também tinha outra filha, por não possuir condições financeiras de sustentar a família, resolveu morar com o futuro agressor da menina. A garotinha tinha apenas quatro anos de idade quando passou a chama-lo de pai e assim o considerava até o dia de sua morte.

Em depoimento na sessão de instrução e julgamento do Tribunal do Júri, realizada no dia 22/05/2018 - ou seja, quase três anos após o acometimento do crime -, a mãe e a irmã da vítima, na condição de testemunhas de acusação, relataram que agressor era uma boa pessoa, apesar das crises de ciúme que costumava manifestar. Porém, no carnaval de 2015, o acusado cometeu a primeira agressão contra a enteada, sufocando-a pelo pescoço, quando ela informou que tinha participado de um bloco de carnaval.

Três meses depois, quando a briga entre eles já havia arrefecido, o padrasto convidou a enteada para participar de uma entrevista de emprego na empresa em que ele trabalhava. Inocente, e com vontade de obter o primeiro registro na carteira de trabalho, a jovem aceitou a proposta. No trajeto para a suposta entrevista de emprego, ele decidiu tomar satisfações de uma tatuagem que a jovem havia feito no braço esquerdo. O desfecho da estória segue descrito abaixo, conforme Sentença de Pronúncia proferida no dia 19/10/2016.

[...] ocasião em que ele estacionou o veículo e passou a agredi-la, batendo sua cabeça contra a coluna do automóvel, deixando-a desorientada, momento em que a colocou no banco de trás do veículo, objetivando abusá-la sexualmente, voltando novamente a espancá-la e asfixiá-la com o cinto de segurança do carro e, em seguida, seguiu pela mencionada rodovia em direção a este município de Itapissuma onde, na localidade denominada Sítio Burro Velho, parou o carro em um canavial, tirou a calça cumprida da vítima e a estuprou [...] (PERNAMBUCO, 2016). 
De acordo com a mãe da vítima, ela chegou a ligar para a filha no momento em que o crime estava sendo cometido. Como a jovem não atendia o telefone, ela resolveu ligar para o marido. Quando ele atendeu a ligação, a mãe escutou os gritos de socorro da jovem. "Nesse momento, eu soube que nunca mais ia ver minha filha", afirmou a mãe de M.A.A.S durante o julgamento. No mesmo dia, ela foi a uma delegacia solicitar o registro do sequestro da filha, mas foi informada que a ocorrência só poderia ser registrada após 48 horas do desaparecimento.

Assim, no dia 22/06/2015, a mãe da vítima compareceu ao Departamento de Homicídios e Proteção à Pessoa (DHPP) e foi nesse momento que começou o espetáculo da imprensa. A cada momento eram divulgadas informações sobre o desaparecimento da jovem, as diligências para encontrar a vítima, a prisão do agressor e, por fim, o achado do corpo no canavial do Sítio Burro Velho, no município de Itapissuma. Mas, apesar da grande cobertura, a mídia não fez referência ao crime como Feminicídio (CORPO, 2015; PADRASTO, 2015).

Naquele momento, apesar de já estar em vigor ${ }^{23}$, a Lei esquecida pela imprensa também pareceu não fazer parte do ordenamento jurídico brasileiro, pois o Inquérito Policial foi finalizado sem qualificar o crime; o Ministério Público ofereceu a Denúncia sem incluir a qualificadora, cuja omissão foi acompanhada pela Sentença de Pronúncia.

PRONUNCIO (...) sujeitando-o a julgamento pelo Tribunal do Júri como incurso no art. 148, $\S 1^{\circ}$, V (sequestro para fins libidinosos); art. $213 \mathrm{c} / \mathrm{c} 226$, II (estupro contra enteada); art. 121, $\$ 2^{\circ}$, I, III, IV e V (homicídio qualificado por motivação torpe, uso de asfixia e meio cruel; meio indefensável e com o fim de assegurar a impunidade ou ocultação de outro crime); e art. 211 (ocultação de cadáver), todos do Código Penal Brasileiro (PERNAMBUCO, 2016).

Por esta razão, o juízo que pronunciou o réu, ao não fazer uso da Emendatio Libelli, impediu que o Conselho de Sentença reconhecesse a prática do Feminicídio. Assim, no dia da sessão do Júri, o promotor foi categórico ao ser questionado pela imprensa sobre o porquê de a qualificadora não ter sido imputada ao réu: "houve falha no processo criminal". Isso significa que o Parquet reconheceu que o Sistema de Justiça Criminal não está suficientemente capacitado para identificar os agentes e as condutas qualificadoras do crime de Feminicídio.

\footnotetext{
${ }^{23}$ A lei no 13.104 não previu o instituto da vacatio legis, entrando em vigor na data da sua publicação, em 09 de março de 2015.
} 
Não obstante a condenação do agressor a 35 anos de reclusão, o crime cometido contra M.A.A.S não consta das estatísticas de Feminicídios ocorridos no Estado de Pernambuco.

\title{
6.2 T.M.S.A. (Processo $n^{0}$ 0007703-38.2017.8.17.0001): a pressão do Movimento Feminista e a pronúncia qualificada do acusado
}

A vítima morava sozinha num prédio de classe média alta, em um bairro nobre do Recife. Na manhã do dia 05/04/2017, a jovem foi abordada dentro de casa pelo vizinho que pretendia, mediante violência ou grave ameaça, manter relações sexuais com ela. Pra não ser estuprada, a moça lutou contra seu agressor até a morte, conforme consta na Pronúncia:

\begin{abstract}
[...] o acusado adentrou no apartamento da vítima, sua vizinha, e mediante grave ameaça exercida com instrumento cortante, com extrema violência, sem a permissão e após vencer a resistência física desta, praticou com a mesma atos libidinosos e, em seguida, como forma de esconder a prática do crime anterior, de modo bastante cruel, de forma que dificultou/impossibilitou qualquer chance de defesa à vítima e em total menosprezo à condição de mulher da vítima, por esgorjamento, matou T.M.S.A., que apesar de muito lutar para não ter sua integridade violada e sua vida interrompida, não teve como resistir (PERNAMBUCO, 2017).
\end{abstract}

$\mathrm{Na}$ semana do crime, a partir da prisão em flagrante do agressor, a imprensa promoveu uma ampla divulgação do episódio que causou a perplexidade pela brutalidade com que foi cometido. A repercussão midiática (GUERRA, 2017; VIZINHO, 2017; JOVEM, 2017) aliada à mobilização do Movimento Feminista, da Secretaria da Mulher (SecMulher/PE) e do Conselho Estadual de Defesa dos Direitos da Mulher (CEDIM/PE), pressionou o Poder Judiciário a converter o Flagrante em Prisão Preventiva (Art. 310, II $^{24}$, c/c, Art. $312^{25}$, ambos do CPP), como de fato aconteceu.

No dia 21/06/2017, foi realizada a audiência de instrução e julgamento, resultando na pronúncia do acusado no dia 29/09/2017. Diferente do que aconteceu com o episódio de M.A.A.S., tanto a imprensa quanto o juiz reconheceram a prática da qualificadora do crime de Feminicídio, conforme tão bem-disposto no texto da Sentença de Pronúncia:

\footnotetext{
24 "converter a prisão em flagrante em preventiva, quando presentes os requisitos constantes do art. 312 deste Código, e se revelarem inadequadas ou insuficientes as medidas cautelares diversas da prisão; ou..."

25 "A prisão preventiva poderá ser decretada como garantia da ordem pública, da ordem econômica, por conveniência da instrução criminal ou para assegurar a aplicação da lei penal, quando houver prova da existência do crime e indício suficiente de autoria e de perigo gerado pelo estado de liberdade do imputado".
} 
Por seu turno, a prova testemunhal demonstra que houve SIM, no caso dos autos, o que a doutrina chama de FEMINICIDIO, agravante do crime introduzida pela Lei 13.104/2015 (...). Nesse diapasão, deverão os jurados emitir decisão a respeito da qualificadora prevista no artigo $121, \S 2^{\circ}$, incisos III, IV, V e VI, do Código Penal (...) (PERNAMBUCO, 2017).

A partir do episódio, a SecMulher/PE e o CEDIM/PE envidaram esforços para que o Governo do Estado instituísse mecanismos de fortalecimento da atuação policial e do Sistema de Justiça Criminal para registro, processamento e julgamento dos Feminicídios em Pernambuco. Assim, cinco meses após a morte brutal de T.M.S.A., foram instituídos os decretos $n^{\circ} 44.950 / 2017$ e $n^{\circ} 44.951 / 2017$, que dispõe sobre o registro da ocorrência do crime no Estado e cria o Grupo de Trabalho Interinstitucional sobre Feminicídio (GTIF), conforme já mencionado neste estudo. Além disso, no dia 13/11/2017, foi sancionada a Lei estadual ${ }^{\circ}$ 16.196, instituindo o 05 de abril como o Dia do Enfrentamento ao Feminicídio em Pernambuco.

No dia 05/08/2019, o agressor foi condenado a 30 anos de prisão, sendo 24 pelo Feminicídio de T.M.S.A. e seis pelo estupro da jovem.

\section{Conclusões}

Os esforços até então implementados pelo Estado brasileiro, a partir da estratégia apontada pelo Movimento Feminista para coibir a prática da violência contra as mulheres, têm se mostrado ainda insuficientes para alcançar o seu objetivo. Porém, na incipiência de outras alternativas mais eficazes, ainda não é possível abandonar o caminho já percorrido, tornandose indispensável aprimorar as ações legislativas, executivas e judiciais, bem como aquelas desenvolvidas pela sociedade civil de uma maneira geral. Nesse sentido, é preciso criticar, propositivamente, o que foi feito e deve ser aperfeiçoado. Tomando como exemplo as iniciativas do Governo de Pernambuco que aqui foram mencionadas, é possível fazer sugestões que poderão contribuir com o alcance de resultados mais satisfatórios no campo da erradicação da violência contra as mulheres.

Nessa direção, observa-se uma falha estrutural na composição dos espaços de articulação criados pelo Governo de Pernambuco para discutir o enfrentamento das agressões (letais ou não) contra as mulheres no território estadual. A Câmara Técnica especializada no tema e o Grupo de Trabalho Interinstitucional sobre Feminicídio (GFIT) não possuem representação do Departamento de Homicídios e Proteção à Pessoa (DHPP) e de juízes(as) das Varas do Tribunal do Júri nas suas composições. Esses dois órgãos, mais do que qualquer 
outro, possuem relação direta com a investigação e o julgamento de Feminicídios e, estranhamente, estão à margem do processo integrativo.

Aprofundando um pouco mais a crítica ao método implementado em Pernambuco para investigar, processar e julgar os Feminicídios, observa-se que, após a sanção da Lei Maria da Penha, em 2006, as delegacias de Atendimento à Mulher perderam a competência para instaurar os inquéritos policiais onde as mulheres figuravam como vítimas fatais, sob o argumento de que a nova legislação traria uma sobrecarga para estes órgãos. Com isso, em vez de melhor estruturá-los para atender a demanda, a opção foi transferir a competência da investigação dos assassinatos de mulheres para o DHPP. Essa medida fez com que os crimes letais contra as mulheres passassem a ser investigados por uma equipe com pouca experiência na temática de gênero, prejudicando a qualificação dos assassinatos de mulheres como Feminicídios.

Seguindo esta mesma lógica, também não foi atribuída às varas de Violência Doméstica e Familiar contra a Mulher a competência para processar os possíveis casos de Feminicídio. Esta tarefa continua sob a competência das varas do Tribunal do Júri que, da mesma forma que o DHPP, não possui expertise na identificação das condutas e/ou circunstâncias que qualificam o crime e, muito menos, priorizam o julgamento dos Feminicídios, como indicam as Diretrizes Nacionais.

De toda sorte, independentemente das indicações aqui apresentadas, é notória a necessidade de capacitação dos agentes do Sistema de Justiça Criminal para a aplicação adequada da qualificadora. A proposta não é tornar o mecanismo de aplicação do Direito Penal em um protagonista no enfrentamento do Feminicídio, mas sim utilizá-lo como ferramenta de registro da real ocorrência do fenômeno na sociedade, visando a proposição de estratégias que passam ao largo do uso simbólico do poder punitivo e sua função instrumental.

\section{Bibliografia}

BRASIL. Decreto-lei no 2.848, de 07 de dezembro de 1940. Código Penal. Disponível em: http://www.planalto.gov.br/ccivil_03/decreto-lei/del2848compilado.htm. Acesso em: 05 jan. 2020. 
BRASIL. Decreto-lei no 3.689, de 03 de outubro de 1941. Código de Processo Penal. Disponível em: http://www.planalto.gov.br/ccivil_03/decreto-lei/del3689.htm. Acesso em: 05 jan. 2020.

BRASIL. Constituição da República Federativa do Brasil, de 05 de outubro de 1988. Disponível em: http://www.planalto.gov.br/ccivil_03/constituicao/constituicao.htm. Acesso em: 05 jan. 2020.

BRASIL. Lei $\mathbf{n}^{0}$ 11.340, de 07 de agosto de 2006. Cria mecanismos para coibir a violência doméstica e familiar contra a mulher, nos termos do $\S 8^{\circ}$ do art. 226 da Constituição Federal, da Convenção sobre a Eliminação de Todas as Formas de Discriminação contra as Mulheres e da Convenção Interamericana para Prevenir, Punir e Erradicar a Violência contra a Mulher; dispõe sobre a criação dos Juizados de Violência Doméstica e Familiar contra a Mulher; altera o Código de Processo Penal, o Código Penal e a Lei de Execução Penal; e dá outras providências. Disponível em: http://www.planalto.gov.br/ccivil_03/_ato20042006/2006/lei/111340.htm. Acesso em: 05 jan. 2020.

BRASIL. Lei $\mathbf{n}^{\mathbf{0}}$ 13.104, de 09 de março de 2015. Altera o art. 121 do Decreto-Lei $\mathrm{n}^{\mathbf{0}} 2.848$, de 7 de dezembro de 1940 - Código Penal, para prever o feminicídio como circunstância qualificadora do crime de homicídio, e o art. $1^{\circ}$ da Lei $\mathrm{n}^{\mathrm{o}} 8.072$, de 25 de julho de 1990, para incluir o feminicídio no rol dos crimes hediondos. Disponível em: http://www.planalto.gov.br/ccivil_03/_Ato2015-2018/2015/Lei/L13104.htm. Acesso em: 05 jan. 2020.

BRASIL, Secretaria de Políticas Para Mulheres/Ministério da Mulher, da Igualdade Racial e dos Direitos Humanos. Diretrizes Nacionais Feminicídio: Investigar, processar e julgar com perspectiva de gênero as mortes violentas de mulheres. Brasília: SPM/PR, 2016.

BRASIL. Conselho Nacional de Justiça. O Poder Judiciário na Aplicação da Lei Maria da Penha. Brasília, 2018.

BRASIL. Supremo Tribunal Federal. Arguição de Descumprimento de Preceito Fundamental 779/DF. Legítima Defesa da Honra. Inconstitucionalidade. Autor: Partido Democrático Tabalhista (PDT). Relator: Min. Dias Toffoli, 26 de fevereiro de 2021. Disponível em: < http://www.stf.jus.br/arquivo/cms/noticiaNoticiaStf/anexo/ADPF779.pdf >. Acesso em: 02 mar. 2021.

BUARQUE, Cristina. Introdução ao Feminismo. In: Gênero e educação: caderno da igualdade nas escolas. Recife: Secmulher, 2013.

CAMPOS, Carmen Hein de. Feminicídio no Brasil: Uma análise crítico-feminista. In: Sistema Penal \& Violência. Porto Alegre, v. 7., n. 1., p. 103-115, jan-jun, 2015.

CARCEDO, Ana. Femicídio en Costa Rica. 1990-1999. Colección teórica no 1 . Costa Rica: Instituto Nacional de Mujeres, 2000.

CORPO da jovem Maria Alice Seabra é encontrado em canavial. JC NE, 24 jun. 2015. Disponível em: https://jc.ne10.uol.com.br/canal/cidades/policia/noticia/2015/06/24/corpo-dajovem-maria-alice-seabra-e-encontrado-em-canavial-187334.php. Acesso em: 20 jun. 2018. 


\section{DIÁRIO DAS LEIS. Livro V - Ordenações Filipinas - Título - XXXVIII - Do que matou} sua mulher por achá-la em adultério. Disponível em: https://www.diariodasleis.com.br/tabelas/ordenacoes/1-274-103-1451-04-05-38.pdf /. Acesso em: 09 abr. 2021.

DIAS, Maria Berenice. A mulher no Código Civil. Disponível em: http://www.mariaberenice.com.br/uploads/18_-_a_mulher_no_c\%F3digo_civil.pdf.

Acesso em: 01 jan. 2020.

GUERRA, Raphael. Caso Mirella: o que revelam as perícias sobre a morte da fisioterapeuta. NE 10, 13 abr. 2017. Disponível em: https://jc.ne10.uol.com.br/colunas/rondajc/2017/04/13/caso-mirella-o-que-revelam-as-pericias-sobre-a-morte-da-fisioterapeuta.

Acesso em: 20 jun. 2018.

INSTITUTO IGARAPÉ. Instituto Igarapé: Pensa, Conecta, Transforma, 2020. Página inicial. Disponível em: https://igarape.org.br/. Acesso em: 05 jan. 2020.

JOVEM morta em flat foi vítima de violência sexual e tortura, diz Polícia Civil de PE. G1 PE, 04 abr. 2017. Disponível em: https://g1.globo.com/pernambuco/noticia/jovem-morta-emflat-foi-vitima-de-violencia-sexual-e-tortura-diz-policia-civil-de-pe.ghtml. Acesso em: 20 jun. 2018.

LIMA, Renato Brasileiro de. Manual de Processo Penal. Salvador: Ed. JusPodivm, 2020.

LOPES JUNIOR, Aury. Direito Processual Penal. 17ª ed. São Paulo: Saraiva, 2020.

LOPES, Maria José Ferreira. De Pandora a Eva: fontes antigas da misoginia ocidental. Diacrítica, Braga, v.26, n.2, p.490-511, 2012. Disponível em http://www.scielo.mec.pt/scielo.php?script=sci_arttext\&pid=S0807-

89672012000200028\&lng=pt\&nrm=iso. Acesso em: 10 abr. 2021.

MARTINS Fernanda; GAUER Ruth M. C. Poder Punitivo e Feminismo: percursos da criminologia feminista no Brasil. Revista Direito e Práxis, Ahead of print, Rio de Janeiro, $2019 . \quad$ Disponível em: https://www.epublicacoes.uerj.br/index.php/revistaceaju/article/download/37925/29808. Acesso em: 01 fev. 2020.

MARTINS, Fernanda. Feminismos Criminológicos. São Paulo: Tirant lo Blanch, 2021.

MELLO, Marília Montenegro Pessoa de. Lei Maria da Pena: uma análise criminológicocrítica. Rio de Janeiro: Revan, 2015.

NUCCI, Guilherme de S. Tribunal do Júri. $5^{\text {a }}$ ed. revista, atualizada e ampliada. Rio de Janeiro: Forense, 2014.

OLIVEIRA, Luciano. Manual de Sociologia Jurídica. Petrópolis: Vozes, 2015.

PADRASTO confessa ter estuprado e estrangulado Maria Alice com cinto. G1 PE, 25 jun. 2015. Disponível em: http://g1.globo.com/pernambuco/noticia/2015/06/padrasto-estuprou-eestrangulou-maria-alice-com-cinto-diz-policia.html. Acesso em: 20 jun. 2018. 
PADRASTO decepou mão de Maria Alice Seabra, diz inquérito. NE 10, Cidades, 04 jun. 2015.

Disponível

em:

https://jc.ne10.uol.com.br/canal/cidades/policia/noticia/2015/07/04/padrasto-decepou-mao-demaria-alice-seabra-diz-inquerito-188709.php. Acesso em: 20 jun. 2018.

PASINATO, Wânia. "Femicídios" e as mortes de mulheres no Brasil. Cad. Pagu, Campinas, n. 37, p.219-246, Dec. $2011 . \quad$ Disponível em http://www.scielo.br/scielo.php?script=sci_arttext\&pid=S0104-

$83332011000200008 \& \operatorname{lng}=$ en\&nrm=iso. Acesso em: 20 jan. 2020.

PERNAMBUCO. Tribunal de Justiça de Pernambuco. Sentença de Pronúncia. Processo ${ }^{\circ}$ 0000686-77.2015.8.17.0790. DJ: 19/10/2016. Judwin, 2016. Disponível em: https://srv01.tjpe.jus.br/consultaprocessualunificada/processo/00006867720158170790.

Acesso em: 20 jun. 2018.

PERNAMBUCO. Tribunal de Justiça de Pernambuco. Sentença de Pronúncia. Processo $\mathrm{n}^{\circ}$ 0007703-38.2017.8.17.0001. DJ: 29/09/2017. Judwin, 2017. Disponível em: https://srv01.tjpe.jus.br/consultaprocessualunificada/processo/00006867720158170790.

Acesso em: 20 jun. 2018.

PERNAMBUCO. Secretaria da Mulher. Planilha com os dados das mortes violentas letais intencionais. 2020.

PITANGUY, Jacqueline. Celebrando os 30 Anos da Carta das Mulheres Brasileiras aos Constituintes. In: Seminários 30 Anos da Carta das Mulheres Brasileiras aos Constituintes. Rio de Janeiro: EMERJ, 2018.

SAFFIOTI, Heleieth Iara Bongiovani. Gênero, Patriarcado e Violência. São Paulo: Expressão Popular; Fundação Perseu Abramo, 2015.

SEVERI, Fabiana Cristina. Lei Maria da Penha e o projeto jurídico feminista brasileiro. Rio de Janeiro: Lumen Juris, 2018.

SILVA, Chistine Oliveira Peter da; GOMIDE, Carolina Freitas. Constitucionalistas Constituintes: uma agenda para o Brasil. In: Constitucionalismo feminista: expressão das políticas públicas voltadas à igualdade de gênero. Salvador: Editora JusPodivm, 2020.

SOUZA, Danielle Paula de Jesus de. Direito Penal das Mulheres: análise sociojurídica sobre a violência contra a mulher e o feminicídio no Brasil. In: RIBEIRO, Wanessa Fernandes (Org.) Mulheres da Advocacia Criminal: temas atuais de direito e processo penal. Florianópolis: Tirant lo Blanch, 2019.

VIZINHO que degolou fisioterapeuta é autuado por feminicídio. Pragmatismo Político, 07 abr. 2017. Disponível em: https://www.pragmatismopolitico.com.br/2017/04/vizinho-quedegolou-fisioterapeuta-e-autuado-por-feminicidio.html. Acesso em: 20 jun. 2018. 